\title{
Nutrient Retention by Multipond Systems: Mechanisms for the Control of Nonpoint Source Pollution
}

\author{
Weijin Yan,* Chengqing Yin, Hongxiao Tang
}

\begin{abstract}
The processes of the multipond system in an experimental agricultural watershed located in southeastern China were studied during a 2-yr period (1994-1995), with the purpose of the research being the reduction of nonpoint nutrient pollution at its sources. The mechanisms studied included water storage capacity, sedimentation, denitrification, and removal of nutrients by the harvest of macrophytes from ponds and ditches. The results showed that the retention of both water and nutrients depended on the water storage capacity of the ponds, the total pond volume, rainfall, surface runoff, and irrigation amounts. For the years of 1994 and 1995 , the water retention rate was $85.5 \%$, while the nutrient retention rate reached 98.1 and $97.8 \%$ for total N (TN) and total P (TP), respectively. Sediment deposit was another important mechanism. The average sedimentation rate was $30.0 \mathrm{~mm} \mathrm{yr}^{-1}$ (from 1985-1995). For the whole multipond system (35 ha), the average retention amounts reached $9800 \mathrm{~kg}$ of $\mathrm{N}$ and 2800 $\mathrm{kg}$ of $P$ by sediment accumulation per year. The results demonstrated that denitrification in ponds and ditches was an important mechanism for removing $\mathbf{N}$ from the watershed. The highest possible rate was more than $0.17 \mathrm{mg} \mathrm{N}^{-1}$ soil during the summer season. The results suggested that the multipond system, which kept water in balance, benefited the water, nutrient, and sediment recycling in the terrestrial ecosystem, as well as helped to reduce agricultural nonpoint pollution at its sources. Therefore, the multipond system, with its low cost in construction and maintenance, is recommended as a good practice both for the control of nonpoint pollution at its sources and for sustainable agricultural development.
\end{abstract}

$\mathrm{T}$ HE MULTIPOND SYSTEM, typical of the landscape of China, is a part of ancient Chinese culture. The use of one or two ponds for receiving surface runoff water from nearby lands has been documented as far back as

W. Yan, C. Yin, and H. Tang, SKLEAC, Research Center for EcoEnvironmental Science, CAS, P.O. Box 2871, Beijing 100085, P.R.C.; W. Yan, Dept. of Environment Quality, Institute of Geography, CAS, Building no. 917, Datun Rd., Beijing 100101, P.R.C. Received 18 July 1997. *Corresponding author (szhang@dls.iog.ac.cn).

Published in J. Environ. Qual. 27:1009-1017 (1998).
3000 yr ago (Yan and Yin, 1995). Since that time, by receiving rainfall and surface runoff ponds have been used in central and southeastern China as drinking and livestock water resources. They have also been used to cultivate fish by receiving domestic wastewater from nearby villages and towns. As agriculture developed, these ponds were gradually linked together with many small ditches to form multipond systems (Fig. 1) and became part of a network of agriculture irrigation (Yin et al., 1993). Until the 1980s, not only were multiponds used for rice (Oryza sativa L.) irrigation and fish cultivation, but pond sediments were also excavated as a commonly used fertilizer. In this way, multipond systems remain keeping corresponding water storage capacity. At the same time, sediments and nutrients are reused many times in the recycling processes between terrestrial and aquatic ecosystems. As a result, both terrestrial and aquatic ecosystems can maintain their own stability (Yin et al., 1994).

Nonpoint source (NPS) pollution was recognized in the late 1960s (Novotny and Chesters, 1981), and since then numerous approaches to control NPS pollution have been applied: treatment of wetlands (Hsieh and Coultas, 1989; Jansson et al., 1994; Johnston, 1991; Mitsch and Gosselink, 1993; Richardson, 1985); buffer zones (Phillips 1989a,b; Muscutt et al., 1993); vegetated filter strips (Dillaha et al., 1989; Lowrance et al., 1985); as well as others.

In China's national eutrophication research project, it was found that scattered multipond systems could effectively retain nutrients from agricultural watersheds (Yin et al., 1993); however, the mechanisms of the retention were not clearly understood. This paper focuses on nutrient retention mechanisms by the multipond systems for the control of NPS pollution, as well as de-

Abbreviations: TN, total nitrogen; TP, total phosphorus; NPS, nonpoint source; TDP, total dissolved phosphorus. 


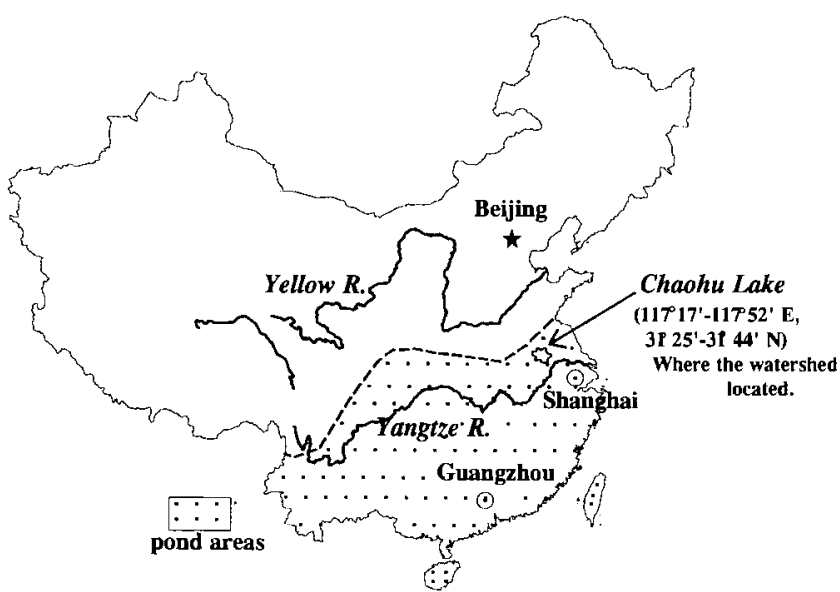

Fig. 1. Locations where multipond systems are widely used.

scribes how nutrient retention depends on particular factors of the systems.

\section{STUDY AREA}

This study was carried out in an experimental agricultural subwatershed in Chaohu Lake during 1994 and 1995. Chaohu Lake is located on a tributary of the Yangtze River and has a surface area of $760 \mathrm{~km}^{2}$. In recent decades, the lake has suffered from intense eutrophication (Tu et al., 1990). The previous studies showed that the NPS nutrient load accounted for $60 \%$ of total $\mathrm{N}$ and $63 \%$ of total $\mathrm{P}$ input (Jin et al., 1990; Wei et al., 1992). Thus, for the management of Chaohu Lake, it is very important to control NPS pollution.

Located on the northern bank of Chaohu Lake, the experimental Liuchahe subwatershed covers an area of 732 ha and a resident population of about 3000 inhabitants living in some 16 small villages. The social and economical situation of this watershed is typical of that of a small-scale subsistence farming community. Like most of the area around the lake, a triple cropping system consisting of early rice, late rice, and rape is used in the irrigated rice fields. Nonirrigated farmlands are normally cultivated with wheat (Triticum aestivum $\mathrm{L}$.), cotton (Gossypium hirsutum L.), potato (Solanum tuberosum L.), peanut (Arachis hypogaea L.), soybean [Glycine max (L.) Merr.], and other vegetables. Chemical fertilizers such as $\mathrm{NH}_{4} \mathrm{HCO}_{3}, \mathrm{CO}\left(\mathrm{NH}_{2}\right)_{2}$, and $\mathrm{Ca}\left(\mathrm{H}_{2} \mathrm{PO}_{4}\right)_{2}$ are increasingly being used in this area. Additionally, farmyard manure and other domestic wastes are also applied to the croplands. There is no industry in the watershed. Thus, all nutrients are considered to be from NPS, including villages. The watershed faces the lake in the southwest direction and is surrounded by low hills in the northeast part, forming a close watershed with a clear border.

\section{Land Use}

The land pattern in the Liuchahe watershed is composed of five types of land use. The distribution and composition of these land use types are shown in Fig. 2. The structure of land

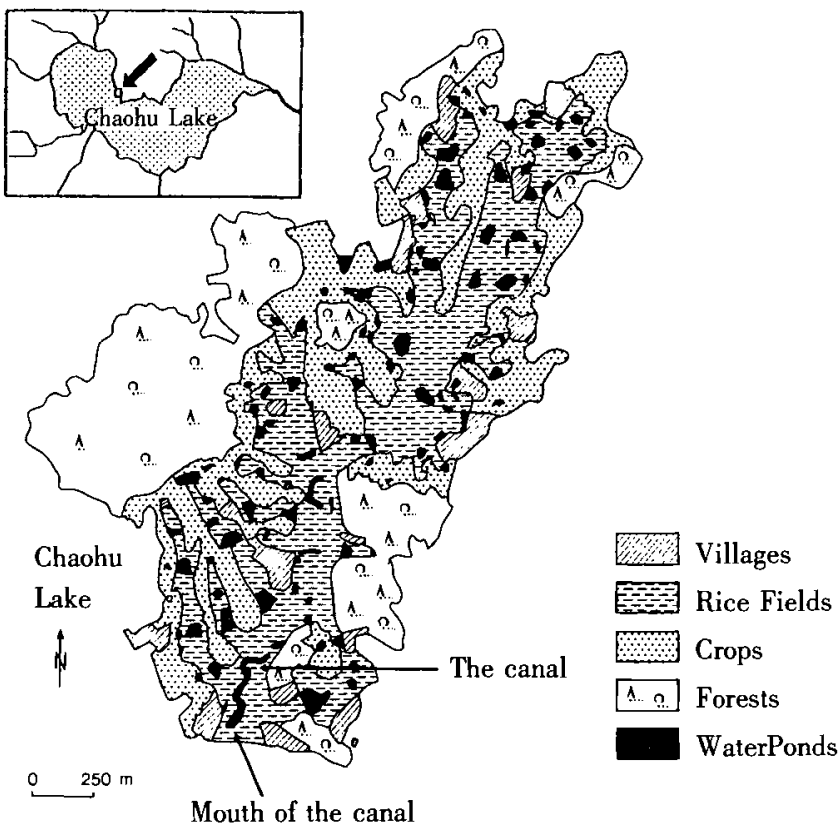

Fig. 2. Location of the experimental agricultural watershed and distribution of the multipond systems.

use is strongly influenced by geomorphologic and hydrological conditions, $17.9 \%$ of the land being occupied by forest, lying on the mountainous areas (131 ha); $31.3 \%$ by nonirrigated farmland (also called crop land, $229 \mathrm{ha}$ ), situated on mounds; $7.1 \%$ by village ( $52 \mathrm{ha}$ ), normally around the top of the mounds; $38.8 \%$ by rice fields ( $284 \mathrm{ha}$ ), located in the plains or saddle between two mounds; and the remaining $4.9 \%$ being occupied by ponds and ditches ( $36 \mathrm{ha}$ ).

\section{Climate}

The 40-yr (1956-1995) mean long-term meteorological records from the local meteorological station were assumed to be representative for the watershed (Table 1). The climate was characterized by the following annual mean values: precipitation $940 \mathrm{~mm} \mathrm{yr}^{-1}$, evaporation $1484.3 \mathrm{~mm} \mathrm{yr}^{-1}$, mean air temperature $15.5^{\circ} \mathrm{C}$, mean relative humidity $77 \%$, and sunshine $2181 \mathrm{hr} \mathrm{yr}^{-1}$.

\section{MATERIALS AND METHODS}

Fifteen ponds in the watershed were chosen for the study, of which three were in the mountainous areas, four in the nonirrigated farmland, three in the rice fields, two near villages, and three along the canal, with one in the canal mouth. In addition, three sections of rice fields, four plots in wooded tracts, and two villages were selected to determine surface runoff and nutrient load.

During the experiment, water samples from the rice fields, ponds, and the canal were taken every $15 \mathrm{~d}$ from 1 April to 31 October of each year. The rainfall and surface runoff water samples were taken only after each rainfall and when surface

Table 1. Long-term (1956-1995) climate characteristics in the Liuchahe watershed.

\begin{tabular}{|c|c|c|c|c|c|c|c|c|c|c|c|c|c|}
\hline Month & 1 & 2 & 3 & 4 & 5 & 6 & 7 & 8 & 9 & 10 & 11 & 12 & Total \\
\hline Sunshine, h & 133.6 & 123.5 & 144.7 & 165.1 & 191.4 & 202.4 & 225.0 & 240.2 & 162.5 & 183.0 & 159.5 & 150.2 & 2181 \\
\hline Precipitation, mm & 28.0 & 45.5 & 73.9 & 93.0 & 95.2 & 118.4 & 179.4 & 106.3 & 77.9 & 49.9 & 47.6 & 24.6 & 940.0 \\
\hline Evaporation, mm & 50.8 & 57.7 & 98.6 & 131.4 & 174.6 & 189.2 & 195.9 & 196.3 & 135.8 & 116.6 & 80.1 & 57.5 & 1484.3 \\
\hline Temperature, ${ }^{\circ} \mathrm{C}$ & 2.2 & 3.7 & 8.8 & 15.4 & 20.9 & 25.1 & 28.0 & 27.8 & 22.6 & 17.0 & 10.5 & 4.3 & \\
\hline Relative humidity, \% & 77 & 78 & 76 & 78 & 76 & 76 & 82 & 80 & 70 & 78 & 76 & 75 & \\
\hline
\end{tabular}


runoff existed. In each plot, surface runoff was measured using precalibrated flumes equipped with water-level recorders, with 5 to 15 samples being collected during each runoff event. Each of the water samples taken was $500 \mathrm{~mL}$. After sampling, $200-\mathrm{mL}$ aliquots of each water sample were filtered on $0.45 \mu \mathrm{m}$ pore-size glassfiber filters. Within $2 \mathrm{hr}$, all the filtered and unfiltered water samples were digested with $\mathrm{K}_{2} \mathrm{~S}_{2} \mathrm{O}_{4}$ solution in a nearby field laboratory, they were stored at $4^{\circ} \mathrm{C}$ until analysis. The digested unfiltered water samples were analyzed for TN and TP; the filtered samples were analyzed for dissolved nitrogen (DN) and dissolved phosphorus (DP). Both the $\mathrm{N}$ and $\mathrm{P}$ were simultaneously determined by using the method of peroxodisulfate oxidation (Ebina et al., 1983).

Surface soils from three sections of rice fields and sediments of 15 ponds were collected. About $1 \mathrm{~kg}$ of the upper $100 \mathrm{~mm}$ of each soil (sediment) profile was sampled, placed in plastic bags, and transported to the laboratory. The samples were air dried and passed through a 2-mm sieve. Organic matter was determined by the dichromate-wet combustion method ( $\mathrm{Ra}$ veh and Avnimelech, 1972), TN by Kjeldahl digestion (Nelson and Sommers, 1972), and TP by perchloric acid digestion (Sommers and Nelson, 1972). Additionally, sediment thickness was directly measured from sediment profiles when ponds were dried to the bottom. Sediment accumulation in each pond was calculated by the product of sediment bulk density and bottom area of each pond. Sedimentation rates are expressed in terms of deposition thickness $\left(\mathrm{mm} \mathrm{yr}^{-1}\right)$ and mass accumulation $\left(\mathrm{g} \mathrm{m}^{-3} \mathrm{yr}^{-1}\right)$. Both the water and soil (sediment) results presented are mean values of duplicate analyses performed on each sample.

Nutrient removal by uptake of macrophytes was calculated by the product of biomass and nutrient content. The dominance, frequency, size of distribution of macrophytes in ponds and ditches were measured to calculate the area of macrophytes. After that, three $1-\mathrm{m}^{2}$ of macrophytes were collected to measure the density of macrophytes (wet wt. $\mathrm{g} \mathrm{m}^{-2}$ ) in each pond or ditch. The samples of macrophytes per unit wet weight were transported to the laboratory and air dried to calculate the ratio of dry to wet weight. Then each species of the airdried macrophytes was cut into pieces and ground down to analyze the contents of TN and TP (Chapman and Pratt, 1978). All the treatments were duplicated. Results were calculated by the following formula:

Nutrient content $\left(\mathrm{mg} \mathrm{g}^{-1}\right.$ dry wt.) $\times$ ratio

(dry wt./wet wt.) $\times$ biomass $\left(\mathrm{g} \mathrm{m}^{-2}\right.$ wet wt.) $\times$ area $\left(\mathrm{m}^{2}\right)$

Denitrification rates were studied by laboratory incubation (Zhu and Wen, 1990), and expressed at $\mathrm{NO}_{3}$ removal capacity (mg $\mathrm{NO}_{3}-\mathrm{N} \mathrm{g}^{-1}$ soil). Approximately $20 \mathrm{~g}$ of dry soil (or sediment) with $40 \mu \mathrm{m}$ in diameter was placed in a $100 \mathrm{~mL}$ glassbottle. Following that, $5 \mathrm{mg} \mathrm{N}$ as $\mathrm{KNO}_{3}$ dissolved in $5 \mathrm{~mL}$ of water, was added. In all cases, $20 \mathrm{~mL}$ of distilled water was

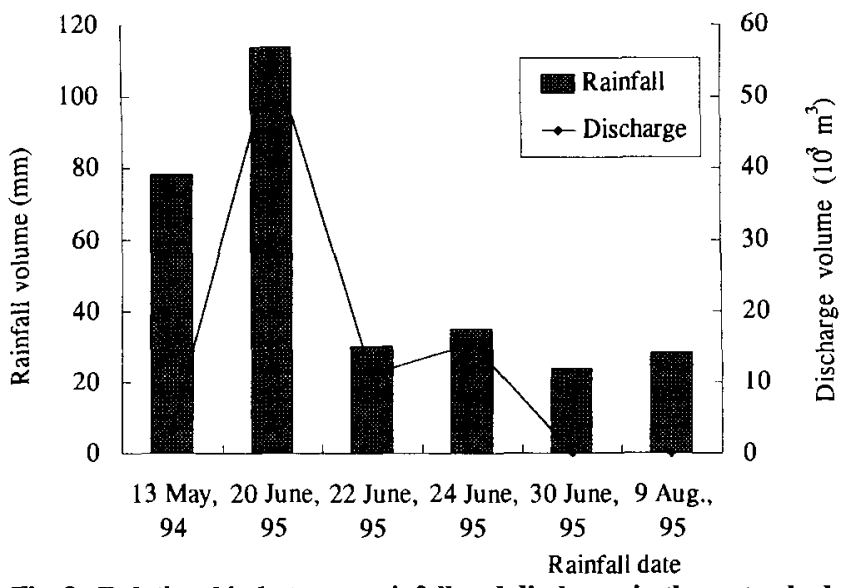

Fig. 3. Relationship between rainfall and discharge in the watershed.

added to bring the total addition of liquid to $25 \mathrm{~mL}$. All the bottles were tightly sealed and incubated under the temperatures of 32,18 , and $11.7^{\circ} \mathrm{C}$, respectively, for 1 to $14 \mathrm{~d}$. A 25 $\mathrm{mL}$ of $\mathrm{KCl}$ solution $(2 M)$ was used to extract nitrate $\left(\mathrm{NO}_{3}\right)$ from each bottle. Initial $\mathrm{NO}_{3}$ concentration of each soil (sediment) was similarly determined before each incubation, and all treatments were duplicated.

Rainfall strength was recorded in millimeters per hour for more than 10 rainfall events. Since light rain did not produce runoff, only data of six medium and heavy rainfalls were used. Water flow rate for discharge at the canal mouth to the lake was determined with a flowmeter. Also, the cross-section area was measured. Surface runoff of different land use for each of the six rainfalls was also determined by directly measuring the runoff volume at the above selected sites at unit time, or by calculating with the curve number hydrological model (Novotny and Chesters, 1981).

In our research, water storage capacity in the multiponds can be calculated by the following formula:

$$
P S=R F+R S-E-I R-D-I F
$$

where

$\mathrm{PS}=$ pond storage capacity, $\mathrm{m}^{3}$

$R F=$ rainfall which directly falls on multiponds, $\mathrm{m}^{3}$

$\mathrm{RS}=$ surface runoff volume, $\mathrm{m}^{3}$

$\mathrm{E}=$ evaporation amount, $\mathrm{m}^{3}$

IR $=$ irrigation amount, $\mathrm{m}^{3}$

$\mathrm{D}=$ discharge amount, $\mathrm{m}^{3}$

$\mathrm{IF}=$ pond infiltration amount, $\mathrm{m}^{3}$

while the water retention rate $=(\mathrm{RS}-\mathrm{D}) / \mathrm{RS} \times 100 \%$.

The nutrient load from different land uses can be calculated by using the following formula:

Table 2. The surface runoff properties of different land uses in the Liuchahe watershed.

\begin{tabular}{|c|c|c|c|c|c|c|c|}
\hline \multirow[b]{2}{*}{ Date } & \multirow[b]{2}{*}{ Precipitation } & \multicolumn{6}{|c|}{ Surface runoff depth of different land uses } \\
\hline & & Forests & Villages & Rice fields & $\begin{array}{l}\text { Nonirrigated } \\
\text { farmlands }\end{array}$ & $\begin{array}{c}\text { Entire } \\
\text { watershed }\end{array}$ & $\begin{array}{c}\text { Pond } \\
\text { storage }\end{array}$ \\
\hline & & & & & & - & $\mathbf{m}^{3}$ \\
\hline \multicolumn{8}{|l|}{1994} \\
\hline$\overline{13 \text { May }}$ & 78.3 & 29.1 & 51.4 & 10.9 & 13.2 & 0.43 & 125900 \\
\hline \multicolumn{8}{|l|}{1995} \\
\hline $\begin{array}{l}20 \text { June } \\
22 \text { June } \\
24 \text { June } \\
\text { 30 June } \\
9 \text { Aug. }\end{array}$ & \begin{tabular}{r|}
$\mathbf{1 1 4}$ \\
$\mathbf{3 0}$ \\
$\mathbf{3 5}$ \\
$\mathbf{2 4}$ \\
$\mathbf{2 8}$
\end{tabular} & $\begin{array}{c}75.7 \\
16.3 \\
17.4 \\
9.20 \\
8.0\end{array}$ & $\begin{array}{l}94.6 \\
24.5 \\
26.3 \\
18.0 \\
19.0\end{array}$ & $\begin{array}{l}18.5 \\
6.90 \\
6.60 \\
l \\
l\end{array}$ & \begin{tabular}{|c|}
28.0 \\
8.80 \\
10.1 \\
1.70 \\
1.20
\end{tabular} & $\begin{array}{c}7.66 \\
1.51 \\
2.10 \\
l \\
I\end{array}$ & $\begin{array}{r}209000 \\
62800 \\
62900 \\
25400 \\
23100\end{array}$ \\
\hline
\end{tabular}


Table 3. Nutrient concentration in surface runoff of different land uses for six rainfalls.

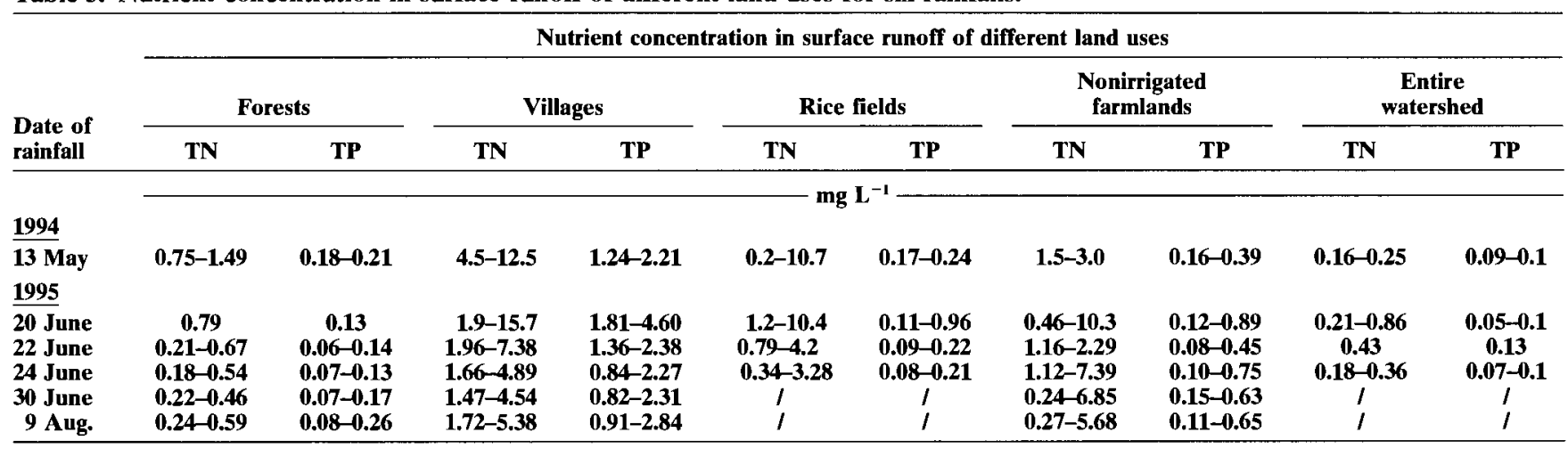

Table 4. The ratio of total dissolved phosphorus (TDP) and total phosphorus (TP) in surface runoff of different land uses.

\begin{tabular}{|c|c|c|c|}
\hline Type of land uses & $\begin{array}{l}\text { TP in surface } \\
\text { runoff water }\end{array}$ & $\begin{array}{l}\text { TDP in surface } \\
\text { runoff water }\end{array}$ & TDP/TP \\
\hline & \multicolumn{2}{|c|}{$\longrightarrow \mathrm{mg} \mathrm{L}^{-1} \longrightarrow$} & $\%$ \\
\hline Rice fields & 0.24 & 0.24 & 100 \\
\hline Villages & 1.24 & 0.97 & 78 \\
\hline Forests & $\mathbf{0 . 1 8}$ & 0.09 & 50 \\
\hline Nonirrigated farmlands & $\mathbf{0 . 1 6}$ & 0.01 & 6.3 \\
\hline
\end{tabular}

$$
\mathrm{LC}=\mathrm{Q} \times \mathrm{C}
$$

where

$\mathrm{LC}=$ nutrient load for each rainfall, $\mathrm{kg} \mathrm{ha}^{-1}$

$\mathrm{Q}=$ surface runoff volume, $\mathrm{m}^{3}$

$\mathrm{C}=$ average nutrient concentration in surface runoff, $\mathrm{mg} \mathrm{L}^{-1}$

The nutrient retention rate can be calculated by using the following formula:

$$
\mathrm{R}=[\mathrm{LC}-(\mathrm{Cn} \times \mathrm{D})] / \mathrm{LC}
$$

where

$$
\begin{aligned}
& \mathrm{Cn}=\text { the measured nutrient concentration at the canal } \\
& \text { mouth to the lake, } \mathrm{mg} \mathrm{L}^{-1} \\
& \mathrm{D}=\text { the measured discharges in volume at the mouth, } \mathrm{m}^{3}
\end{aligned}
$$

\section{RESULTS AND DISCUSSION}

Through a 2-yr field experiment and study in the Liuchahe subwatershed, we found that the nutrient retention by the multipond system within the watershed was controlled by the following four factors: (i) water storage capacity of multiponds; (ii) sedimentation in multiponds; (iii) denitrification of sediments in multiponds; (iv) harvest of marcophytes from multiponds.

\section{Water Storage Capacity}

In the Liuchahe subwatershed, the nutrient load to the lake was mainly driven by rainfall and surface runoff. The retention and removal of nutrients were strongly influenced by hydrological conditions. Surface runoff carried nutrients to ditches and ponds, which then received water with dissolved and particulate nutrients. This load varied greatly with the amount of runoff, and with density and duration of rainfall. Hence, the water storage capacity of ponds was a relatively permanent mechanism in controlling NPS pollution. During the studied period, six medium and heavy rainfall events capable of producing runoff were measured, and the total precipitation was $319.3 \mathrm{~mm}$ (Table 2). The surface runoff depths of different land use, and discharges of the watershed are shown in Table 2. With the six rainfall events on the watershed, the total surface runoff volume was $506200 \mathrm{~m}^{3}$, based on field measurement and calculation for all fields. Our measurements showed that only $14.5 \%$ was discharged into the lake at the canal mouth, indicating that the average retention rate for water was $85.5 \%$. However, the rate was different for each rainfall. For example, because of severe drought in 1994, most ponds were dried to the bottom. When there was a rainfall of $78.3 \mathrm{~mm}$ in $13 \mathrm{May}, 1994$, there was only 0.43 $\mathrm{mm}(2.50 \%)$ runoff depth discharge in the canal mouth,

\begin{tabular}{|c|c|c|c|c|c|c|c|c|c|c|}
\hline \multirow[b]{3}{*}{ Rainfall } & \multicolumn{10}{|c|}{ Nutrient load in different land uses } \\
\hline & \multicolumn{2}{|c|}{ Forests } & \multicolumn{2}{|c|}{ Villages } & \multicolumn{2}{|c|}{ Rice fields } & \multicolumn{2}{|c|}{$\begin{array}{c}\text { Nonirrigated } \\
\text { farmlands }\end{array}$} & \multicolumn{2}{|c|}{$\begin{array}{c}\text { Entire } \\
\text { watershed }\end{array}$} \\
\hline & TN & $\mathbf{T P}$ & TN & $\mathbf{T P}$ & TN & $\mathbf{T P}$ & $\mathbf{T N}$ & $\mathbf{T P}$ & $\mathbf{T N}$ & $\mathbf{T P}$ \\
\hline $\mathbf{m m}$ & & & & & - & -1 & & & & \\
\hline 78.3 & 0.326 & 0.057 & 4.36 & 0.89 & 0.593 & 0.022 & 0.297 & 0.037 & 0.726 & 0.094 \\
\hline 114 & 0.598 & 0.098 & 8.33 & 3.03 & 1.07 & 0.099 & 1.51 & 0.141 & 1.586 & 0.315 \\
\hline 30 & 0.072 & 0.016 & 1.14 & 0.457 & 0.172 & 0.011 & 0.152 & 0.023 & 0.208 & 0.046 \\
\hline 35 & 0.063 & 0.017 & 0.863 & 0.410 & 0.119 & 0.010 & 0.43 & 0.042 & 0.253 & 0.049 \\
\hline 24 & 0.031 & 0.010 & 0.540 & 0.282 & 1 & 1 & 0.06 & 0.007 & 0.063 & 0.024 \\
\hline 28 & 0.033 & 0.014 & 0.675 & 0.356 & I & 1 & 0.036 & 0.005 & 0.065 & 0.029 \\
\hline Total & 1.12 & 0.212 & 15.91 & 5.43 & 1.96 & 0.142 & 2.49 & 0.26 & 2.87 & 0.56 \\
\hline
\end{tabular}
and thus the water retention rate reached $97.5 \%$. For another heavy rainfall on $114 \mathrm{~mm}$ of 20 June 1995, the discharge was $7.66 \mathrm{~mm}(21.2 \%)$. But for the medium

Table 5. Nutrient load in different land uses after each of six rainfalls. 
rainfall of 30 to $35 \mathrm{~mm}$ on 22 and 24 June 1995 , the discharge reached $1.51(15.0 \%)$ and $2.10(19.7 \%) \mathrm{mm}$. For the 24 and $28 \mathrm{~mm}$ rainfalls on 30 June and 9 August, the discharge disappeared, and the water retention rate reached $100 \%$, the main reason being that pond water was pumped to meet the irrigation need for the rice fields. Therefore, the water budget in the multiponds was strongly influenced by pond storage capacity, as well as rainfall volume, density, and frequency. Over the entire 2-yr period, the relationship between discharge amount and rainfall volume in the watershed did not show a linear relationship $\left(r^{2}=0.79\right.$, Fig. 3$)$, as reported by other researchers (Rossi et al., 1991), because the multiponds played an important role in water retention.
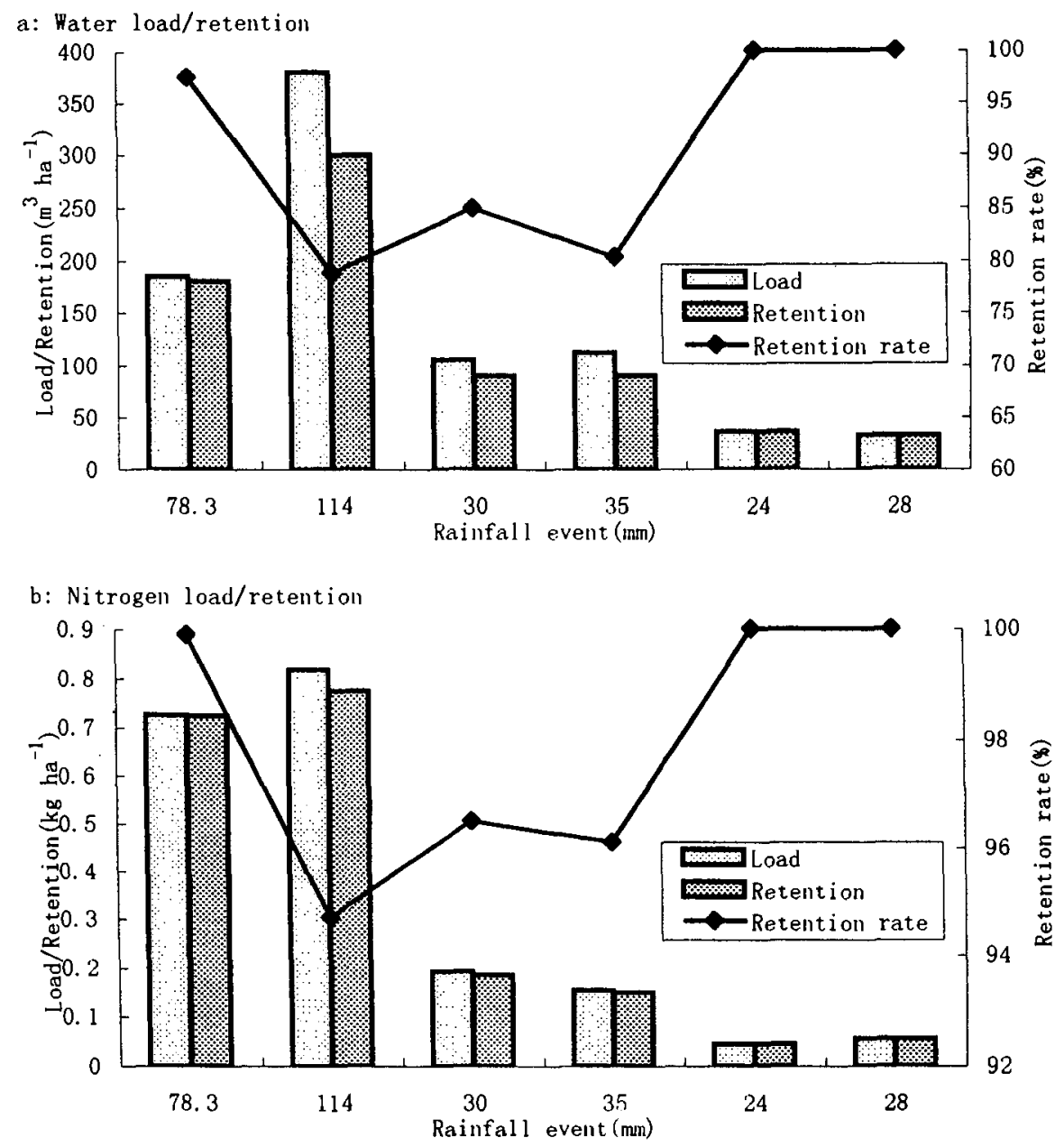

c: Phosphorus

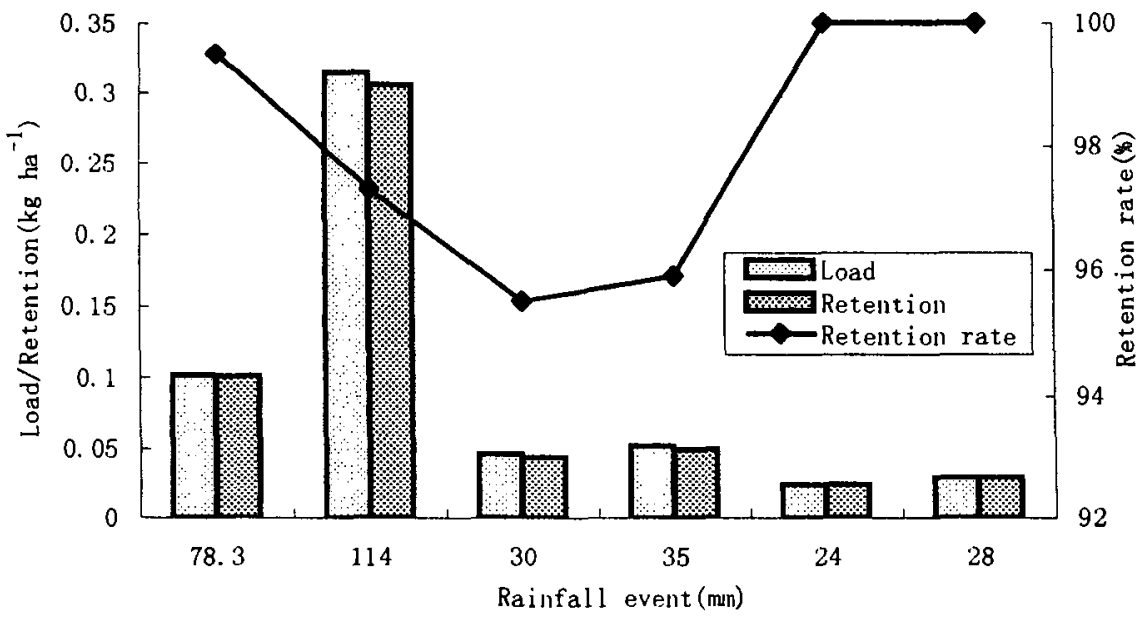

Fig. 4. Water and nutrient retention for each rainfall event, and retention in percent of the load. 
In this way, nutrients were also retained in the multiponds.

The average nutrient concentrations in surface runoff for each rainfall are presented in Table 3 . The nutrient concentrations in surface runoff varied with different land uses. No relationship was found between runoff volume and the concentrations of nutrients $\left(\mathrm{TN}, r^{2}=\right.$ 0.73 ; TP, $r^{2}=0.77$ ), and this observation is consistent with other studies (McDowell et al., 1989; $\mathrm{Ng}$ et al., 1993). The portions of nutrients in surface runoff water varied with land uses. For $\mathrm{P}$ (Table 4), the dissolved form (TDP) was only $6.3 \%$ of the TP in surface runoff water from nonirrigated farmlands. From rice fields, almost all $\mathrm{P}$ was in dissolved form.

The total annual nutrient load is the sum of each rainfall. The results of nutrient load for the different land uses are presented in Table 5. In 1994 and 1995, $2100 \mathrm{~kg}\left(2.87 \mathrm{~kg} \mathrm{ha}^{-1}\right)$ of TN and $410 \mathrm{~kg}\left(0.56 \mathrm{ha}^{-1}\right)$ of TP were delivered to the multiponds from surface runoff. Of these, the largest $\mathrm{N}$ load was from villages, reaching $827.3 \mathrm{~kg}$ of TN $\left(15.91 \mathrm{ha}^{-1}\right)$. The second was from nonirrigated farmlands, reaching $570 \mathrm{~kg}\left(2.49 \mathrm{~kg} \mathrm{ha}^{-1}\right)$, while $557 \mathrm{~kg}\left(1.96 \mathrm{~kg} \mathrm{ha}^{-1}\right)$ came from rice fields and $147 \mathrm{~kg}\left(1.12 \mathrm{~kg} \mathrm{ha}^{-1}\right)$ from forests. For the P load, villages still ranked first, reaching $282.4 \mathrm{~kg}\left(5.43 \mathrm{~kg} \mathrm{ha}^{-1}\right)$. The second source was from nonirrigated farmlands, reaching $60.0 \mathrm{~kg}\left(0.26 \mathrm{~kg} \mathrm{ha}^{-1}\right)$, while rice fields brought $40.3 \mathrm{~kg}\left(0.142 \mathrm{~kg} \mathrm{ha}^{-1}\right)$ and the forest $28.0 \mathrm{~kg}(0.212 \mathrm{~kg}$ $\mathrm{ha}^{-1}$ ). From the analysis of nutrient load, livestock has been identified as the major source of nutrient pollution. Although villages occupy a small portion of land use, nutrient flux from villages was still the main input to the multiponds. The reason is that manure in the villages is generally stored in very shallow holes and is easily washed out into multiponds with surface runoff. The second nutrient load was from nonirrigated farmlands. Results in Table 5 also show that generally nutrient loads in all the land uses were positively correlated with rainfall volumes $\left(r^{2}=0.95\right)$, since more rainfall caused greater surface runoff containing greater nutrient amounts.

The rates of both water and nutrient retention for each rainfall are shown in Fig. 4. The average nutrient retention rate was 98.1 and $97.8 \%$ for TN and TP, respectively, in 1994 and 1995 . The results demonstrate that the rate of nutrient retention was higher than that of water retention for each rainfall event. From the view point of energy, we found that the fundamental mechanisms of retention processes depend on a progressive decrease of dynamic energy of moving water (Fig. 5). Therefore, before the surface runoff water discharges into Chaohu Lake, it should flow through a series of ditches and ponds. In pond after pond, most water, sediments, and nutrients are retained and stored in the multipond system by reducing both the runoff volume and nutrient concentrations through the processes of sedimentation of particles, absorption of dissolved nutrients, denitrification of $\mathrm{NO}_{3}$ in the sediments, and uptake of nutrients by macrophytes.

\section{Sediments and Nutrient Traps}

Sediment retention of nutrients was relatively irreversible in the multiponds. Table 6 shows the contents

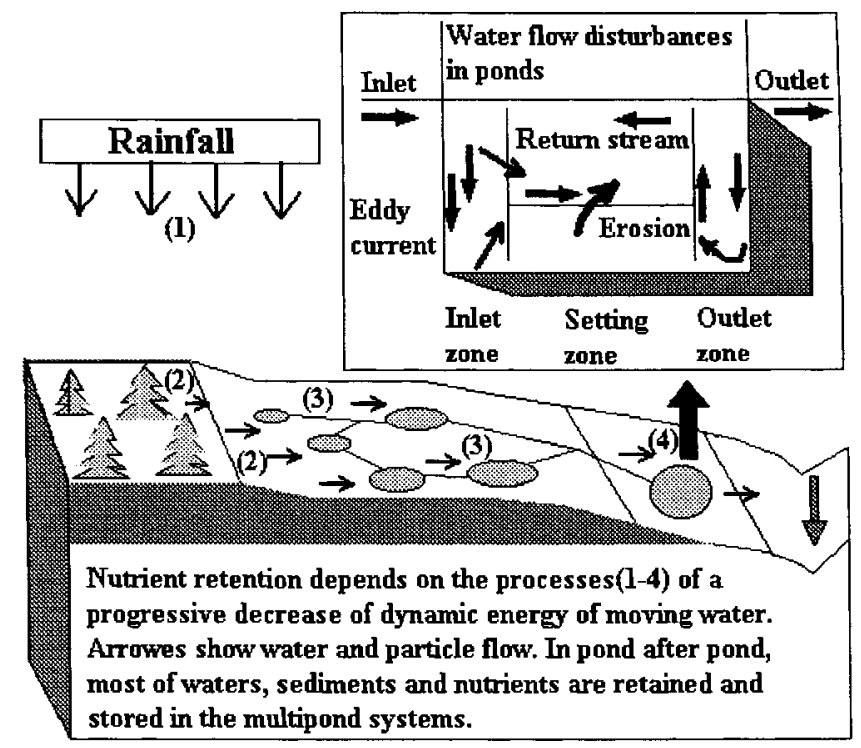

Fig. 5. The processes of water and particle flow showing a progressive decrease of the dynamic energy.

of TN, TP, and OM in multipond sediment and Table 7 shows annual thickness and mass accumulation rates for pond sediments. The results demonstrated the following:

I. Although the difference of nutrient contents in different ponds is not significant (Table 6), ponds around mountainous areas still had the lowest nutrient accumulation (529 $\mathrm{g} \mathrm{m}^{-2} \mathrm{yr}^{-1} \mathrm{TN}$ and $\left.195 \mathrm{~g} \mathrm{~m}^{-2} \mathrm{yr}^{-1} \mathrm{TP}\right)$ and the highest OM content ( $20.5 \mathrm{~g} \mathrm{~kg}^{-1}$ sediment) in their sediments, because no fertilizer was applied to these sandstone hills, except the deposit of the litter of pine trees.

II. Villages had little influence on the pond sediment nutrients, although nutrient loads from them were highest (seeing Table 5); 'mainly, nutrients were in dissolved form.

III. Ponds within nonirrigated farmlands had relatively high nutrient accumulation $\left(1020 \mathrm{~g} \mathrm{~m}^{-2} \mathrm{yr}^{-1} \mathrm{TN}\right.$ and $279 \mathrm{~g} \mathrm{~m}^{-2} \mathrm{yr}^{-1} \mathrm{TP}$ ) caused by soil erosion during rainfall events, but the lowest $\mathrm{OM}\left(6.63 \mathrm{~g} \mathrm{~kg}^{-1}\right.$ sediment).

IV. Rice fields had more influence on sediment nutrients of the ponds within them; the nutrient accumulations were highest $\left(1149 \mathrm{~g} \mathrm{~m}^{-2} \mathrm{yr}^{-1} \mathrm{TN}\right.$ and $306 \mathrm{~g} \mathrm{~m}^{-2}$

Table 6. The contents of total $N$, total $P$, and organic matter (OM) in pond sediments.

\begin{tabular}{|c|c|c|c|}
\hline $\begin{array}{l}\text { Sample pond } \\
\text { location } \dagger\end{array}$ & TN (NS\&) & TP (NS) & OM* \\
\hline & \multicolumn{3}{|c|}{$\mathrm{g} \mathrm{kg}^{-1}$ sediment } \\
\hline 1 & 1.25 & 0.46 & 20.5 \\
\hline 2 & 1.94 & 0.53 & 6.63 \\
\hline 3 & 2.14 & 0.57 & 7.21 \\
\hline 4 & 1.8 & 0.53 & 8.90 \\
\hline 5 & 1.93 & 0.49 & 14.3 \\
\hline Avg. & 1.81 & 0.52 & 11.5 \\
\hline SD $\ddagger$ & 0.30 & 0.04 & 5.30 \\
\hline
\end{tabular}


Table 7. Annual thickness and mass accumulation rates for sediments in the multiponds.

\begin{tabular}{|c|c|c|c|c|}
\hline \multirow{2}{*}{$\begin{array}{l}\text { Sample pond } \\
\text { location' } \dagger\end{array}$} & \multirow{2}{*}{$\begin{array}{c}\text { Thickness accretion } \\
* * *\end{array}$} & \multicolumn{3}{|c|}{ Mass accumulation } \\
\hline & & $\mathbf{T N} * * *$ & $\mathbf{T P} * * *$ & Sediment $\left(\times 10^{4}, \mathrm{NS}\right)$ \\
\hline & $\operatorname{mm} y^{-1}$ & & $-\mathbf{g}$ & \\
\hline 1 & 12.0 & 529 & 195 & 42.3 \\
\hline 2 & 58.0 & 1020 & 279 & 52.6 \\
\hline 3 & 16.0 & 1149 & 306 & 53.7 \\
\hline 4 & 40.0 & 1040 & 306 & 57.8 \\
\hline 5 & 25.0 & 936 & 238 & 48.5 \\
\hline Avg. & 30.0 & 935 & 265 & 51.0 \\
\hline SD $\ddagger$ & 16.9 & 214 & 42.9 & 5.30 \\
\hline
\end{tabular}

*** Significant at the 0.01 probability level.

† Sample 1 refers to sediment in ponds around mountainous areas, 2: ponds within nonirrigated farmlands, 3: ponds within rice fields, 4: ponds near villages 5: ponds along the canal.

$+\mathrm{SD}=$ standard deviation.

$\S \mathbf{N S}=$ not significant.

$\mathrm{yr}^{-1} \mathrm{TP}$ ); possibly because the overflow from rice fields could only transfer small particles, and such particles have a strong sorptive capacity.

Our study indicated that the average thickness of sediments was $30.0 \mathrm{~mm} \mathrm{yr}^{-1}$ (Table 7), while ponds within nonirrigated farmlands had the highest rate, reaching $58.0 \mathrm{~mm} \mathrm{yr}^{-1}$ and ponds in mountainous areas had the lowest rate $\left(12.0 \mathrm{~mm} \mathrm{yr}^{-1}\right)$. The study also demonstrated that the mean nutrient contents of sediments were $1.81 \mathrm{~g}$ TN and $0.52 \mathrm{~g}$ TP per kilogram sediment. The nutrient accumulation in sediment was 935 and 265 $\mathrm{g} \mathrm{m}^{-3}$ per year for TN and TP. The total amount of nutrients in pond sediments was $9800 \mathrm{~kg} \mathrm{yr}^{-1}$ of TN and $2800 \mathrm{~kg} \mathrm{yr}^{-1}$ of TP. Therefore, it may be necessary to excavate nutrient-saturated sediments and transport them back to the agricultural source sites to reduce the nutrient export. One characteristic of the multipond system is that water and nutrients can be recycled many times in the watershed.

\section{Denitrification Rates}

Denitrification rates of soils and sediments in different sites were measured by the removal rate of $\mathrm{NO}_{3}$ during anaerobic incubations under temperatures of 32 , 18 , and $11.7^{\circ} \mathrm{C}$. The results are shown in Fig. 6. Denitrification is a microbial process that occurs under anaerobic conditions and is influenced by organic $\mathrm{C}$ content, $\mathrm{N}$ content, temperature, and other factors. From Fig. 6, we observed that denitrification rates varied greatly in

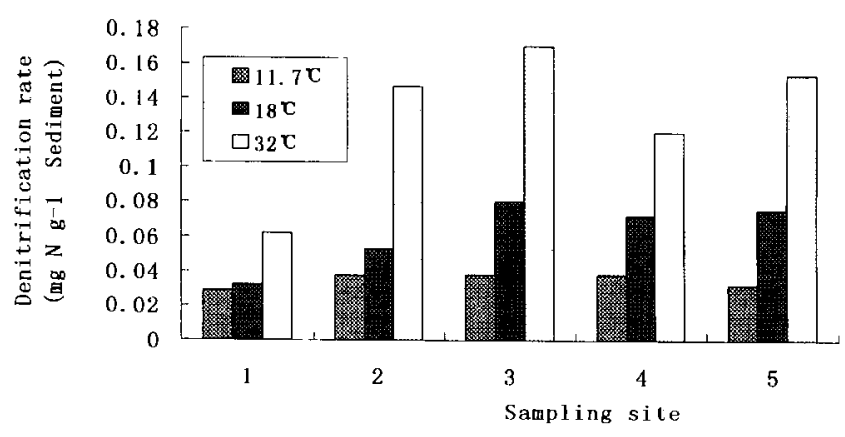

1: sediments in ponds of mountainous area;

2: sediments in ponds of nonirrigated farmland:

3: sediments in ponds of rice field;

4: sediments in the canal:

5: soil from rice fields

Fig. 6. Denitrification rates of sediments in ponds of different sites. sediments of different ponds. For example, at $32^{\circ} \mathrm{C}$, denitrification rates varied from 0.062 to $0.17 \mathrm{mg} \mathrm{N} \mathrm{g}^{-1}$ sediment for 7-d incubations. The highest rate occurred in sediment of ponds among rice fields $\left(0.17 \mathrm{mg} \mathrm{N} \mathrm{g}^{-1}\right.$ sediment), while the lowest rate was in sediment of ponds in mountainous areas. This variation is closely related to the content of TN (seeing Table 6 and 7, $r^{2}=$ $0.99)$ and the accumulation of TN $\left(r^{2}=0.91\right)$. Besides, it is also related to the ratio of the contents of $\mathrm{OM}$ and TN $\left(r^{2}=-0.89\right)$. At $11.7^{\circ} \mathrm{C}$, the rates in all sediments varied little $\left(0.029-0.038 \mathrm{mg} \mathrm{N} \mathrm{g}^{-1}\right.$ sediment), and were much lower than that at $32^{\circ} \mathrm{C}$. Therefore, temperature has a great impact on denitrification rate. In addition, the rate would increase with an increase in incubation time. The annual denitrification losses on $\mathrm{N}$ in the entire watershed was estimated to be $5400 \mathrm{~kg}$.

\section{Nutrient Uptake by Macrophytes}

Nutrient uptake by macrophytes is given in Table 8 . With the harvest of vegetation, nutrients were removed from the multipond systems. The total amount of nutrients removed was $191 \mathrm{~kg} \mathrm{TN} \mathrm{yr}^{-1}$ and $24.0 \mathrm{~kg} \mathrm{TP} \mathrm{yr}^{-1}$. In addition, macrophytes may improve conditions for denitrification in $\mathrm{NO}_{3}$-rich ditches and ponds by supplying organic $\mathrm{C}$, which is used directly by denitrifying bacteria in the reducing sediment zones. Mechanisms through which macrophytes may influence denitrification of $\mathrm{NO}_{3}$ applied to the multipond system were as follows (Weisner et al., 1994):

1. Supply detritus to increase organic C.

2. Extracellular release of DOC from leaves.

3. Provide attachment surface to bacteria.

4. Increase oxygen consumption in the sediment.

5. A lowered redox potential to stimulate denitrification.

Table 8. The species and biomass of dominant macrophytes in the multiponds.

\begin{tabular}{lcccc}
\hline Species & Biomass & Area & $\begin{array}{c}\text { Content } \\
\text { of } \mathrm{N}\end{array}$ & $\begin{array}{c}\text { Content } \\
\text { of P }\end{array}$ \\
\hline $\begin{array}{l}\text { Potamogeton } \\
\text { crispus }\end{array}$ & $\mathrm{g} \mathrm{m}^{-2}$, wet wt. & $\mathrm{m}^{2}$ & $-\mathrm{mg} \mathrm{g}^{-1}$ & wet wt. - \\
$\begin{array}{c}\text { Myriophyllum } \\
\text { verticillata }\end{array}$ & 1780 & 13400 & 4.04 & 0.54 \\
$\begin{array}{l}\text { Phragmites } \\
\text { communis trin }\end{array}$ & 1600 & 11300 & 2.77 & 0.32 \\
\hline
\end{tabular}


Table 9. The surface runoff potential of different land uses under normal meterological and hydrological conditions.

\begin{tabular}{|c|c|c|c|c|c|}
\hline \multirow[b]{2}{*}{ Month } & \multirow[b]{2}{*}{ Precipitation } & \multicolumn{4}{|c|}{ Surface runoff potential of different land uses } \\
\hline & & Nonirri. farmlands & Villages & Forests & Rice fields \\
\hline 1 & & & & & \\
\hline 2 & $\begin{array}{l}28.0 \\
455\end{array}$ & 0.46 & 9.92 & 0.82 & 0.00 \\
\hline 3 & 73.9 & $\begin{array}{c}4.72 \\
18.0\end{array}$ & $\begin{array}{l}23.4 \\
48.4\end{array}$ & 20.90 & 0.00 \\
\hline 4 & 93.0 & 29.6 & 66.1 & 32.7 & 0.00 \\
\hline 5 & 95.2 & 30.9 & 68.1 & 34.1 & 0.00 \\
\hline 6 & 118.4 & 47.2 & 90.2 & 51.2 & 20.0 \\
\hline 7 & 179.4 & 95.7 & 149.5 & 99.8 & 80.0 \\
\hline 8 & 106.3 & 38.7 & 78.8 & 42.3 & 10.0 \\
\hline 9 & 77.9 & 20.3 & 52.1 & 22.9 & 0.00 \\
\hline 10 & 49.9 & 6.4 & 27.9 & 7.8 & 0 \\
\hline 11 & 47.6 & 5.45 & 25.1 & 6.72 & 0.00 \\
\hline 12 & 24.6 & 0.14 & 7.68 & 0.34 & 0.00 \\
\hline Total & 940.0 & 297.6 & 647.2 & 325.0 & 110 \\
\hline
\end{tabular}

Therefore, the system should be managed in such a way as to obtain a mixed emergent and submergent vegetation composition, promoting not only $\mathrm{N}$ removal, but also natural conservation values of the multipond system.

\section{Designing the Multipond System for Both Nutrient Pollution Control at its Sources and Sustainable Agriculture in China}

At the present time, because of the construction of modern reservoirs and development of wells and irrigation canal networks, the multipond systems are no longer being used for water supply. In addition, large amounts of chemical fertilizers are being used instead excavating pond sediments. Pond storage capacity is decreasing, and the importance of ponds for irrigation purposes has also declined. To restore the multipond system for the purpose of nutrient and water retention, it is necessary to design the pond storage capacity. The curve number model (Novotny and Chesters, 1981) may be used:

$$
\mathrm{Q}=(\mathrm{P}-0.2 \mathrm{~S})^{2} /(\mathrm{P}+0.8 \mathrm{~S})
$$

and

$$
\mathrm{S}=(25400 / \mathrm{CN})-254
$$

If we suppose the antecedent soil moisture condition is AMC II, the curve number $\mathrm{CN}$ of hydrological soil group for forest, village, and nonirrigated farmland would be 73,90 , and 71 respectively. By using rainfall data from Table 1, the greatest surface runoff potentials of different land uses would be calculated as in Table 9. The total surface runoff depths for nonirrigated farmland, village, and forest would be 297.6, 647.2, and 325.0 $\mathrm{mm}$, respectively, and the corresponding runoff volumes would be $6.82 \times 10^{5}, 3.36 \times 10^{5}$ and $4.26 \times 10^{5} \mathrm{~m}^{3}$. If we suppose that the rice field can hold a water depth of $10 \mathrm{~cm}$, the surface runoff potential becomes $110 \mathrm{~mm}$, and the runoff volume $3.12 \times 10^{5} \mathrm{~m}^{3}$. Therefore, under normal hydrological conditions, the total surface runoff potential would be $17.56 \times 10^{5} \mathrm{~m}^{3}$. If this volume of runoff water is totally retained in the multiponds, the area of the ponds becomes 59 ha, with a depth of $3 \mathrm{~m}$. This volume of water can meet the needs of seepage loss, evaporation, and irrigation for rice fields. To build such a multipond system, only a small area and a small labor investment are necessary. Correspondingly, it would require only a small investment and little electric power to run and manage this system. The multipond system does benefit both the environment and agriculture production. It is a good example of sustainable agricultural development.

\section{CONCLUSIONS}

Multipond systems of the Liuchahe subwatershed showed very high nutrient retention capacities, with 98.1 and $97.8 \%$ retention rates for TN and TP, respectively, during the experimental period. Of the four retention mechanisms discussed above, the water storage capacity of multiponds is of most importance. Ponds designed for nutrient retention should have an area of 59 ha and be $3 \mathrm{~m}$ in depth to retain total surface runoff under normal hydrological conditions. The multipond system's function of keeping a water balance benefited the water, sediment, and nutrient retention in the terrestrial ecosystem and also helped to reduce NPS pollution from the agricultural watershed at its source. The water and nutrients can easily be reused for irrigation of rice fields and other farm lands. Sedimentation was a relatively irreversible mechanism of nutrient removal when water was retained in ponds. For the 10-yr span of 1986 to 1995 , the total thickness in ponds was about $300 \mathrm{~mm}$. At this rate most ponds will have disappeared in $30 \mathrm{yr}$. This will result in more loss of water and nutrients from the watershed. The excavation of sediments from ponds should be recovered, and nutrient-rich sediments must be sent back to the croplands. This benefits both the water storage capacity of ponds as well as agriculture production. Measures for $\mathrm{N}$ removal in the multipond system must depend on denitrification. In summary, the multipond systems are a good method for China to use in the control of NPS pollution.

\section{ACKNOWLEDGMENTS}

This study is sponsored by the National Natural Sciences Foundation of China (49371062 and 49771067) and the Postdoctoral Science Foundation of China. We express our appreciation to Pu Song, Xiaoyong Han, and Shouxian Xia (Anhui Hydrology Service) for field and laboratory assistance, 
and thanks to Dr. Nelson Belzile for English correction of the manuscript.

\section{REFERENCES}

Chapman, D.H., and F.P. Pratt. 1978. Methods of analysis for soils, plants and waters. p. 150-151, 161-172. Div. of Agricultural Sciences, Univ. of California, Riverside.

Dillaha, T.A., R.B. Reneau, S. Mostaghimi, and D. Lee. 1989. Vegetative filter strips for agricultural non-point source pollution control. Trans. ASAE 32:513-519.

Ebina, J., T. Tsutsui, and T. Shirai. 1983. Simultaneous determination of total nitrogen and phosphorus in water using peroxodisulfate oxidation. Water Res. 17:1721-1726.

Hsieh, Y.P., and C.L. Coultas. 1989. Nitrogen removal from freshwater wetlands: Nitrification-denitrification coupling potential. p. 493500. In D.A. Hammer (ed.) Constructed wetlands for wastewater treatment, municipal, industrial and agricultural. Lewis Publ., Chelsea, MI.

Jansson, M., R. Anderson, H. Berggren, and L. Leonardson. 1994. Wetlands and lakes as nitrogen traps. Ambio 23(6):320-325.

Jin, X., H. Liu, Q. Tu, Z. Zhang, and X. Zhu. 1990. Lake eutrophication in China. (In Chinese.) p. 1-5, 103-115. Environmental Sciences Press of China, Beijing, China.

Johnston, C.A. 1991. Sediment and nutrient retention by freshwater wetlands: Effects on surface water quality. Crit. Rev. Environ. Control 21(5,6):491-565.

Lowrance, R.R., R. Leonard, and J. Sheridan. 1985. Managing riparian ecosystems to control nonpoint pollution. J. Soil Water conserv. 40:87-91.

McDowell, L.L., G.H. Willis, and C.E. Murphree. 1989. Nitrogen and phosphorus yields in run-off from silty soils in Mississippi Delta, U.S.A. Agric. Ecosyst. Environ. 25:119-137.

Mitsch, W.J., and J.G. Gosselink. 1993. Wetlands. 2nd ed. Van Nostrand Reinhold Co., New York.

Muscutt, A.D., G.L. Harris, S.W. Bailey, and D.B. Davies. 1993. Buffer zones to improve water quality: A review of their potential use in UK agriculture. Agric. Ecosyt. Environ. 45:59-77.

Nelson, D.W., and L.E. Sommers. 1972. A simple digestion procedure for estimation of total nitrogen in soils and sediment. J. Environ. Qual. 1:423-425.
Ng, H.Y.F., T. Mayer, and J. Marsalek. 1993. Phosphorus transport in runoff from a small agricultural watershed. Water Sci. Technol. 28(3-5):451-460.

Novotny, V., and G. Chesters. 1981. Handbook of nonpoint pollution, source and management. Van Nostrand Reinhold Co., New York.

Phillips, J.D. 1989a. An evaluation of the factors determining the effectiveness of water quality buffer zones. J. Hydrol. 107:133-145.

Phillips, J.D. 1989b. Nonpoint source pollution control effectiveness of riparian forests along a coastal plain river. J. Hydrol. 110:221-237.

Raveh, A., and Y. Avimelich. 1972. Potentiometric determination of soil organic matter. Soil Sci. Soc. Am. Proc. 36:967.

Richardson, C.J. 1985. Mechanisms controlling phosphorus retention capacity in freshwater wetlands. Science (Washington, DC) 21 : $1424-1427$

Rossi, N., C. Ciavatta, and L.V. Antisari. 1991. Seasonal pattern of nitrate losses from cultivated soil with subsurface drainage. Water Air Soil Pollut. 60:1-10.

Sommers, L.E., and D.W. Nelson. 1972. Determination of total phosphorus in soils: A rapid perchloric acid digestion procedure. Soil Sci. Soc. Am. Proc. 36:902-904.

Tu, Q.Y., D.X. Gu, C.Q. Yin, Z.R. Xu, and J.Z. Han. 1990. Chaohu Lake eutrophication study. University Press of Science and Technology of China (In Chinese), Hefei, China.

Wei, A.X., G.D. Zhao, and C.Q. Yin. 1992. The nutrient budget of Chaohu Lake. J. Environ. Sci. (China) 4(2):17-26.

Weisner, S.E.B., P.G. Eriksson, W. Graneli, and L. Leonardson. 1994. Influence of macrophytes on nitrate removal in wetlands. Ambio 23(6):363-366

Yan, W.J., and C.Q. Yin. 1995. The structure, function, protection and utilization of the artificial multi-pond wetlands. p. 209-216. In Y.Y. Chen (ed.) Study of wetlands in China. Jilin Sciences Technology Press (In Chinese), Changchun, China

Yin, C.Q., Z.W.Lan, and W.J. Yan. 1994. The use of constructed multipond wetlands for the control of agricultural nonpoint pollution. $p$. 580-588. In Proc. of 4th Int. Conf. on Wetland Systems for Water Pollution Control, Guangzhou, China.

Yin, C.Q., M. Zhao, W.G. Jin, and Z.W. Lan. 1993. A multi-pond system as a protective zone for the management of lakes in China. Hydrobiologia 251:321-329.

Zhu, Z.L. and Q.X. Wen. 1990. China soil nitrogen. Jiangsu Science and Technology Press (In Chinese), Nanjing, China. 